\title{
Delayed Cutting Stage in Dual Purpose Wheat: A Better Strategy to Control Weeds and Enhance Forage Production
}

\author{
Muhammad Owais Iqbal ${ }^{1 *}$, Muhammad Zahir Afridi, Muhammad Mehran Anjum, Mehran Ali, Salman Ali and \\ Arsalan khan \\ Department of Agronomy, The University of Agriculture, Pakistan \\ Submission: February 20, 2018; Published: April 04, 2018 \\ "Corresponding author: Muhammad Owais Iqbal, Department of Agronomy, The University of Agriculture, Peshawar, Pakistan, \\ Email: owaisiqbal@aup.edu.pk
}

\begin{abstract}
Green fodder accessibility is a serious issue for livestock, especially in crop land areas where fodder crops cannot be sown due to competition with staple food crops like wheat. The aim of the study was to estimate reduction in weeds density in dual purpose wheat crop utilized for forage and grain production under different cutting stages. Wheat variety Atta-Habib was sown at Palatoo Research Farm (PRF), The University of Agriculture Peshawar, during 2014-15, for fodder and grain production. The five treatments were consisting of no-cut and one cut i.e. at Zadok growth stage 12 or 14 or 16 or 18 . The experiment was laid out in randomized complete block (RCB) design with four replications and plot size $3 \times 3 \mathrm{~m}^{2}$. Results showed that fodder production was increased while weeds fresh and dry weight were reduced with delaying cutting stage from ZGS-12 to ZGS-18, whereas biological and grain yield were also decreased from 13354 to $9949 \mathrm{~kg} \mathrm{ha}^{-1}$ and from 4552 to 3086 respectively with delayed cutting. No cut results highest weeds density $\left(241 \mathrm{~m}^{-2}\right)$ as compared to cut at ZGS 18 i.e. $\left(131 \mathrm{~m}^{-2}\right)$. From all findings it was concluded that no cut is optimum to obtain higher grain yield $\left(4542 \mathrm{~kg} \mathrm{ha}^{-1}\right)$ and highest biological yield $\left(13354 \mathrm{~kg} \mathrm{ha}^{-1}\right)$ but cut at ZGS-18 is optimum for forage production (1865 $\mathrm{kg} \mathrm{ha}^{-1}$ ) as well as for reduction in yield losses due to weeds. About $48 \%$ weeds control and highest green fodder may be obtained with a reduction of $1466 \mathrm{~kg} \mathrm{ha}^{-1}$ in grain yield and $3405 \mathrm{~kg} \mathrm{ha}^{-1}$ in biological yield.
\end{abstract}

Keywords: Dual purpose wheat; Zadok growth stages; Fodder production; Weeds Density; Yield

\section{Introduction}

Among all the cereals wheat (Triticum aestivum) is most important on the basis of production. In Pakistan it occupies about $66 \%$ of the annual food cropped area [1]. It is a rich source of quality forage, protein, energy, nutrients and low in fiber. Wheat has the potential to meet the food and feed requirements of the rapidly growing human and livestock population from the same piece of land under optimum management practices [2]. Wheat can be grown non-traditionally to attain maximum benefit for both grains and feed Shuja et al. [3] to diminish fodder shortage during winter. Wheat has the great potential to regrow and set seed for their dual-purpose cultivation [4]. Forage availability is reduced during the winter period; therefore cereals as dual purpose crop can be used to provide good quality forage and also increases the area for grain production [5]. The fodder scarcity in winter is one of the main warning factors for livestock production. About six million acres wheat in Mexico is cultivated for dual- purpose to nourish three million stocker cattle in fall
[6]. However, many reports suggested that dual purpose wheat crop produce lower grain production. For example Borman et al. [7] reported that yield reduction depends on a combination of timing, intensity and extent of grazing.

Therefore, keeping in view the current demand of both grain and fodder production and yield losses due to weeds, this experiment was conducted to determine optimum cutting stage suitable for dual purpose wheat and weed population control. The objectives of the study were to quantify the impact of cutting a wheat crop for fodder purpose and letting it to re-grow for seed production and to evaluate the response of important characteristics of wheat to different cutting stage. These characteristics were weeds $\mathrm{m}^{-2}$, weeds fresh weight, weeds dry weight, green fodder yield, grain yield and biological yield.

\section{Materials and Methods}

The experiment was conducted during winter season 201415 at Palatoo Research Farm (PRF), Amir Muhammad Khan 
Campus Mardan, The University of Agriculture Peshawar. The five treatments were consisting of no-cut and one cut i.e. at Zadok growth stage (ZGS) 12,14,16 or 18. The experiment was laid out in Randomized Complete Block Design (RCBD) having four replications. The plot size was $3 \times 3 \mathrm{~m}^{2}$. The soil was ploughed up to $30 \mathrm{~cm}$ depth twice by using common cultivator followed by planking to break the clods. The wheat variety Atta-Habib was sown at the rate of $120 \mathrm{~kg} \mathrm{ha}^{-1}$ manually in each plot. Nitrogen and phosphorus were applied at the rate of 120 and $60 \mathrm{~kg} \mathrm{ha}^{-1}$ using urea and DAP respectively. All phosphorus was applied at the time of sowing. Half nitrogen was applied at tillering stage, while the remaining half of the nitrogen was applied before boot stage. The cutting of fodder carried out with the help of sickle along with the ground level at each specific stage. The data was recorded on different parameters as: Weeds were collected by hand weeding, counted and converted to weeds $\mathrm{m}^{-2}$. Weeds collected from $1 \mathrm{~m}^{2}$ were weighted by digital balance to find weeds fresh weight $\mathrm{m}^{-2}$. For weeds dry weight $\mathrm{m}^{-2}$, weeds were dried in oven for 24 hours and weighted by digital balance. The biological yield, each plot was harvested, dried in sun for seven days and then weighted by digital balance. The yield was then converted to $\mathrm{kg} \mathrm{ha}^{-1}$. The wheat grain yield after threshing were collected and weighted to record grain yield in $\mathrm{kg} \mathrm{m}^{-2}$. Then it was converted to $\mathrm{kg} \mathrm{ha}^{-1}$. The green fodder yield was determined by weighting fresh fodder when it was harvested. Then fodder yield in $\mathrm{kg} \mathrm{m}^{-2}$ was converted to $\mathrm{kg} \mathrm{ha}^{-1}$. Data collected were analyzed statistically according to procedure relevant to RCB design. Upon significant F-Test, least significance difference (LSD) test was used for mean comparisons as clarified via [8].

\section{Results and Discussion}

\section{Weeds density \& biomass}

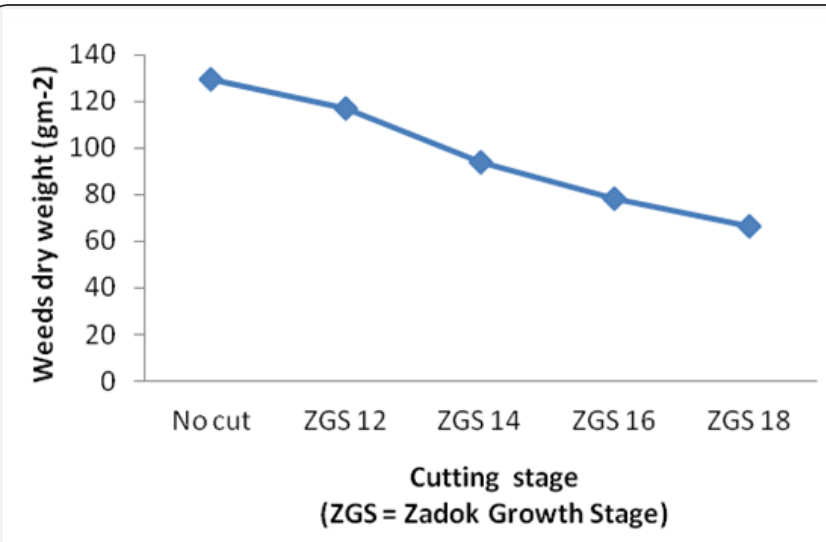

Figure 1: Effect of cutting stage on weeds density $\mathrm{m}^{-2}$ in dual purpose wheat.

The data about weeds density, weeds fresh weight and dry weight is represented in Figure 1-3 respectively. Weeds density as well as fresh and dry weights was extensively affected by cutting stages. The highest weeds density (241) was observed in no -cut plots, whereas lowest weeds density (131) was observed with delaying the cutting stage (to ZGS- 18). Similarly weeds fresh and dry weight was also reduced (from 413 to $220 \mathrm{~g} \mathrm{~m}^{-2}$ ) and (from 130 to $66 \mathrm{~g} \mathrm{~m}^{-2}$ ) respectively with delaying cutting stage. These results are in line with those of Ali et al. [9] and Kirkegaard et al. [10] but do not agree with agree with results of Saleem et al. 2015. Dual-purpose crop can also generate similar benefits while providing a break crop for weeds and disease to clean up Paddocks for subsequent cereals.. In our study, cutting of the crop 70 days after sowing also suppressed weed density and thus their fresh and dry biomass. It may be due to cutting of weeds with the crop and quicker recovery of the crop after cutting [10] (Figure 4 \& 5).

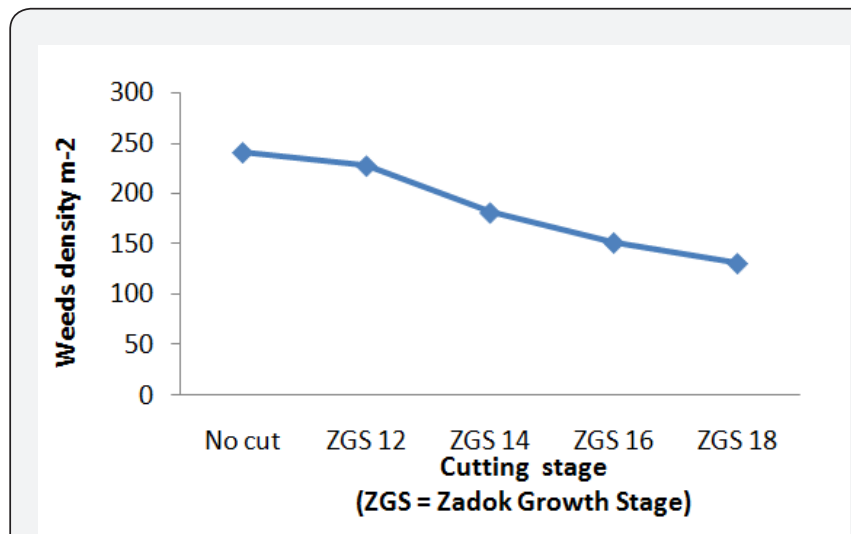

Figure 2: Effect of cutting stage on weeds fresh weight $(\mathrm{g})$ in dual purpose wheat.

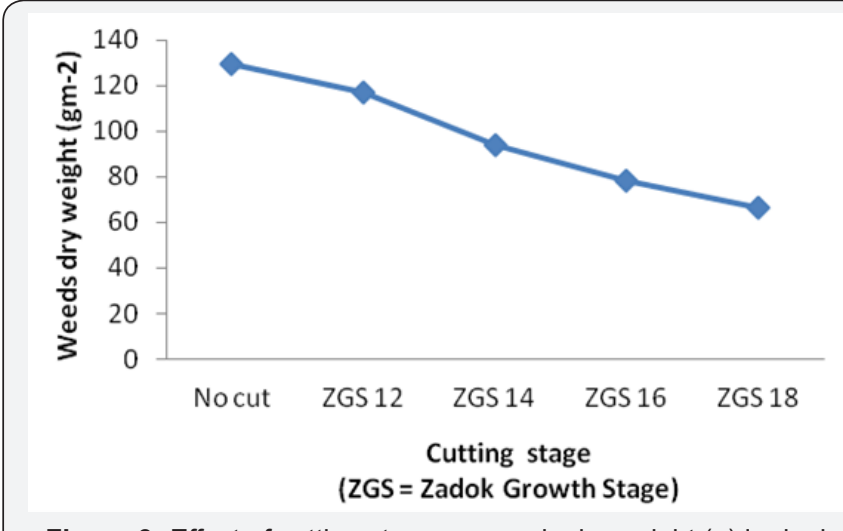

Figure 3: Effect of cutting stage on weeds dry weight $(\mathrm{g})$ in dual purpose wheat.

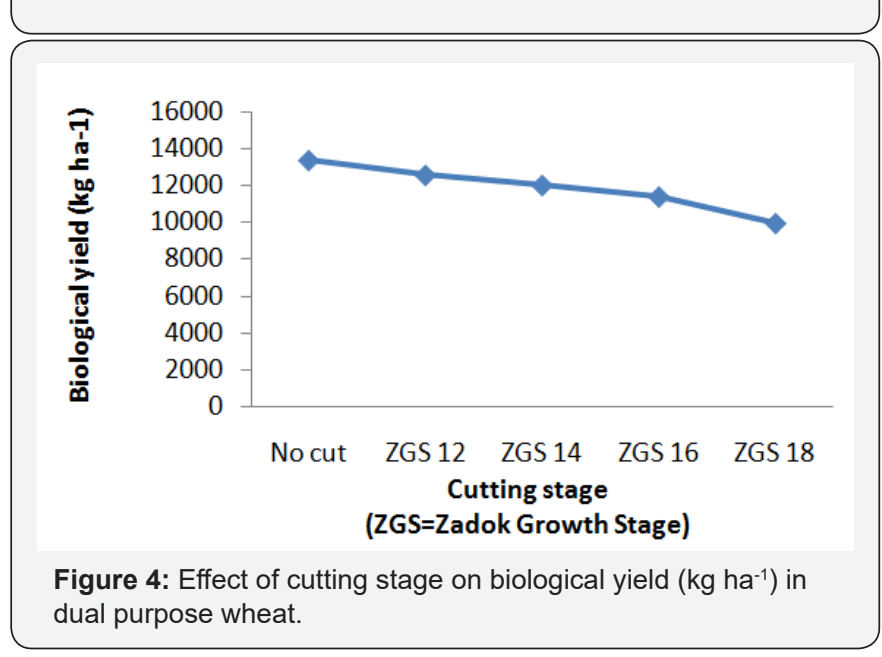




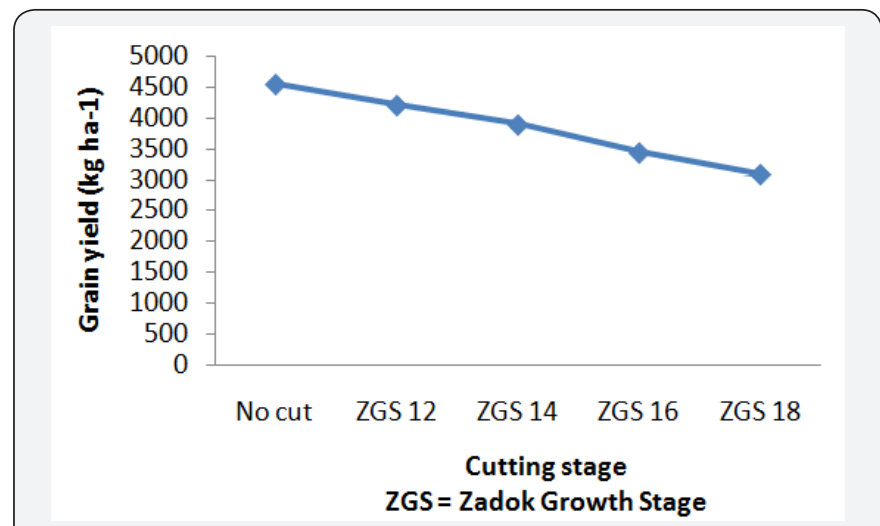

Figure 5: Effect of cutting stage on grain yield $\left(\mathrm{kg} \mathrm{ha}^{-1}\right)$ in dual purpose wheat.

\section{Biological yield (kg ha-1)}

The data about biological yield is represented in Figure 6. Biological yield was significantly affected by cutting stages. The highest biological yield (11500 $\mathrm{kg} \mathrm{ha}^{-1}$ ) was observed in no-cut plots, whereas lowest biological yield (9050kg ha-1) was observed with delaying the cutting stage (to ZGS-18). This reduction is due to removal of whole biomass during cut at ZGS$12,14,16$ or 18 , due to which secondary growth could not face the deficiency, due to shortage of time and nutrients. Afridi et al. [11] also reported reduced vegetative and reproductive biomass production with removal of flag leaf from wheat. The present results confirmed the earlier findings of Iqbal et al. [12], Naveed et al. [13] and Khalil et al. [2].

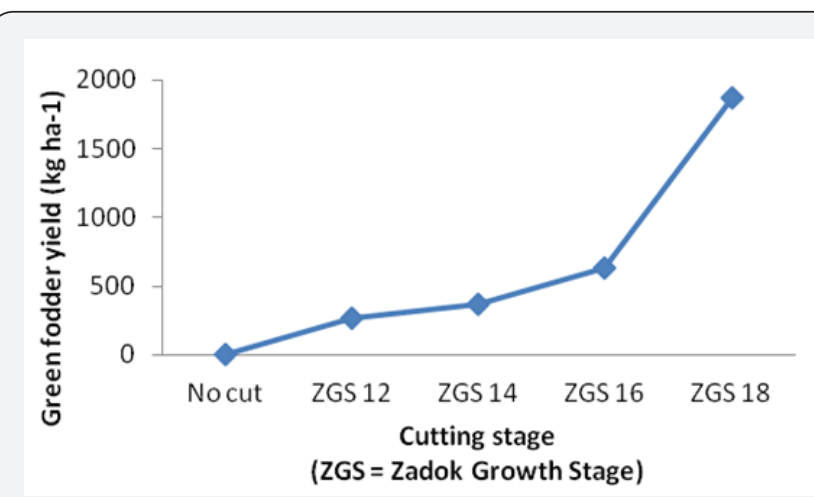

Figure 6: Effect of cutting stage on Green fodder yield $\left(\mathrm{kg} \mathrm{ha}^{-1}\right)$ in dual purpose wheat.

\section{Grain yield (kg ha-1)}

The data about grain yield is represented in Figure 6. Grain yield was considerably affected by cutting stages. The highest grain yield ( $4400 \mathrm{~kg} \mathrm{ha}^{-1}$ ) was observed in no-cut plots, whereas the lowest grain yield $\left(2750 \mathrm{~kg} \mathrm{ha}^{-1}\right)$ was observed with delaying the cutting stage (to ZGS-18). Removal of leaves considerably reduced grain yield of wheat [14]. Similar results were also reported by Shuja et al. [3], Hastenpflug et al. [15] and Larson et al. [16].

\section{Green fodder yield ( $\left.\mathrm{kg} \mathrm{ha}^{-1}\right)$}

The data about green fodder yield is represented in Figure 6. Green fodder yield was significantly affected by cutting stages. The lowest green fodder yield $\left(210 \mathrm{~kg} \mathrm{ha}^{-1}\right)$ was observed in cut at ZGS-12, whereas the highest green fodder yield ( $3500 \mathrm{~kg} \mathrm{ha}^{-1}$ ) was observed with delaying the cutting stage (to ZGS-18). Early cut resulted in lower forage dry matter as compared to late cut. It is due to increase in biomass in growing days in between ZGS-12 and ZGS-18. Iqbal et al. [12] and Khaleel et al. [2] also reported the same results [17-19].

\section{Conclusion}

From all results it was concluded that cutting stage effect is highly significant. Highest green fodder productivity and lowest weeds density \& biomass were observed in plots having cut at ZGS-18. Whereas highest biological yield and grain yield were observed in no cut plots. Therefore keeping in view the above conclusion the recommendations can be given that no cut is recommended on the basis grain yield and biological yield, while on the basis of weeds control strategy and green fodder yield, cut at ZGS-18 is recommended.

\section{References}

1. MINFAL (2008) Agricultural Statistics of Pakistan. Ministry of Food, Agriculture and Livestock, Islamabad, Pakistan.

2. Khalil SK, Khan F, Rahman A, Muhammad F, Amanullah AZ, et al. (2011) Dual purpose wheat for forage and grain yield in response to cutting, seed rate and nitrogen levels. Pak J Bot 43(2): 937-947.

3. Shuja MN, Dure-Nayab AM, Iqbal A, Khalil IH (2010) Evaluating the response of Wheat Genotypes to Forage Clipping. Int'l J Agric Biol 12(1): 111-114.

4. Francia E, Pecchioni N, Nicosia OLD, Paogetta G, Taibi V, et al. (2006) Dual-purpose barley and oat in a Mediterranean. Env J Field Crops Res 99(2-3): 158-166.

5. Arzadun MJ, Arroquy JI, Laborde HE, Brevedan RE (2006) Effect of planting date, clipping height and cultivar on forage and grain yield of winter wheat in Argentinean pampas. Agron 98: 1274-1279.

6. Zhang XC, Phillips WA, Garbrecht JD, Steiner JL, Hunt LA (2008) A wheat-grazing model for simulating grain and beef production. Agron J 100(5): 1242-1247.

7. Borman MM, Louhaichi M, Johnson DE, Krueger WC, Karow RS, et al. (1997) Yield mapping to document goose grazing impact on winter wheat. Agron J 94(5): 1087-1093.

8. Jan MT, Shah P, Hollington PA, Khan MJ, Sohail Q (2009) Agriculture Research: Design and Analysis, A monograph. NWFP Agric Univ Pesh Pak.

9. Ali K, Arif M, Khan Z, Tariq M, Waqas M, et al. (2013) Effect of cutting on productivity and associated weeds of canola. Pak J Weed Sci Res 19(4): 393-401.

10. Kirkegaard J, Sprague SJ, Marcroft SJ, Potter TD, Graham J, et al. (2008a) Identifying canola varieties for dual-purpose use. "Global Issues-Paddock Action. Proceedings of the $14^{\text {th }}$ Aust. Agron Conf, 21-25 September, Adelaide, South Australia.

11. Afridi MZ, Jan MT, Arif M, Jan A (2010) Wheat yielding components response to different levels of fertilizer-N application time and decapitation stress. Sarhad J Agric 26(4): 499-506. 
12. Iqbal MO, Afridi MZ, Akhtar K, Munsif F, Ha VN, et al. (2016) Cutting Stages Influency on Wheat Crop Dry Matter Production and Yield Components. American-Eurasian J Agric \& Environ Sci 16(5): 960-968.

13. Naveed K, Khan MA, Baloch MS, Ali K, Nadim MA, et al. (2014) Effect of different seed rates on yield attributes of dual-purpose wheat. Sarhad J Agric 30(1): 83-91.

14. Abdoli M, Saeid M, Honarmand SJ, Ghobadi ME, Mirza KC (2013) Effect of source and sink limitation on yield and some agronomic characteristics in modern bread wheat cultivars under post anthesis water deficiency. Acta agriculturae Slovenica 101(2): 173-182

15. Hastenpflug M, Martin TN, Braida JA, Barbosa DK, Zielinski RP, et al (2011) Grain yield of dual-purpose wheat cultivars as affected by nitrogen and cuttings. Bragantia Campinas 70(4): 819-824.
16. Larson K, Krenzer E, Kochenower R (2005) Irrigated dual purpose wheat planting dates, seeding rates, varieties in Southeastern Colorado.

17. Arif M, Khan MA, Akbar H, Sajjad, Ali S (2006) Prospects of wheat as a dual purpose crop and its impact on weeds. J Weed Sci Res 12(1/2): 13-18.

18. Munsif F, Arif M, Tariq M, Jan, Khan MJ (2013) Phenology of dual purpose wheat cultivars as influenced by planting dates. Scholarly Journal of Agricultural Science 3(9): 340-350.

19. PBS (2015) Pakistan Bureau of Statistics Report 2014-15. Ministry of National Food Security \& Research, Govt. of Pakistan Islamabad, Pakistan.
This work is licensed under Creative

Commons Attribution 4.0 License

DOI: 10.19080/ARTOAJ.2018.15.555945
Your next submission with Juniper Publishers will reach you the below assets

- Quality Editorial service

- Swift Peer Review

- Reprints availability

- E-prints Service

- Manuscript Podcast for convenient understanding

- Global attainment for your research

- Manuscript accessibility in different formats

( Pdf, E-pub, Full Text, Audio)

- Unceasing customer service

Track the below URL for one-step submission https://juniperpublishers.com/online-submission.php 